\title{
Soybean and casein hydrolysates induce grapevine immune responses and resistance against Plasmopara viticola
}

\section{Nihed Lachhab ${ }^{1}$, Simona M. Sanzani ${ }^{1}{ }^{*}$, Marielle Adrian ${ }^{2}$, Annick Chiltz $^{3}$, Suzanne Balacey ${ }^{2}$, Maurizio Boselli ${ }^{4}$, Antonio Ippolito ${ }^{1}$ and Benoit Poinssot ${ }^{2 *}$}

' Dipartimento di Scienze del Suolo, della Pianta e degli Alimenti, Università degli Studi Aldo Moro, Bari, Italy

2 Université de Bourgogne, UMR 1347 Agroécologie, Pôle Interactions Plantes Micro-organismes - ERL CNRS 6300, Dijon, France

3 INRA, UMR 1347 Agroécologie, Pôle Interactions Plantes Micro-organismes - ERL CNRS 6300, Dijon, France

${ }^{4}$ Dipartimento di Biotecnologie, Università degli Studi di Verona, San Floriano, Italy

Edited by:

Laurent Zimmerli, National Taiwan University, Taiwan

Reviewed by:

Christian Staehelin, Sun Yat-sen University, China

Gabor Jakab, University of Pecs, Hungary

\section{*Correspondence.}

Simona M. Sanzani, Dipartimento di Scienze del Suolo, della Pianta e degli Alimenti, Università degli Studi Aldo Moro, Via G. Amendola 165/A, 70126 Bari, Italy

e-mail: simonamarianna.sanzani@ uniba.it;

Benoit Poinssot, Université de Bourgogne, UMR 1347 Agroécologie, Pôle Interactions Plantes Micro-organismes - ERL CNRS 6300, 17 rue Sully, 21000

Dijon, France

e-mail: benoit.poinssot@dijon.inra.fr
Plasmopara viticola, the causal agent of grapevine downy mildew, is one of the most devastating grape pathogen in Europe and North America. Although phytochemicals are used to control pathogen infections, the appearance of resistant strains and the concern for possible adverse effects on environment and human health are increasing the search for alternative strategies. In the present investigation, we successfully tested two protein hydrolysates from soybean (soy) and casein (cas) to trigger grapevine resistance against $P$. viticola. On Vitis vinifera cv. Marselan plants, the application of soy and cas reduced the infected leaf surface by 76 and $63 \%$, as compared to the control, respectively. Since both hydrolysates might trigger the plant immunity, we investigated their ability to elicit grapevine defense responses. On grapevine cell suspensions, a different free cytosolic calcium signature was recorded for each hydrolysate, whereas a similar transient phosphorylation of two MAP kinases of 45 and $49 \mathrm{kDa}$ was observed. These signaling events were followed by transcriptome reprogramming, including the up-regulation of defense genes encoding pathogenesis-related (PR) proteins and the stilbene synthase enzyme responsible for the biosynthesis of resveratrol, the main grapevine phytoalexin. Liquid chromatography analyses confirmed the production of resveratrol and its dimer metabolites, $\delta$ - and $\varepsilon$-viniferins. Overall, soy effects were more pronounced as compared to the cas ones. Both hydrolysates proved to act as elicitors to enhance grapevine immunity against pathogen attack.

Keywords: protein hydrolysates, Plasmopara viticola, Vitis vinifera, induced resistance, plant immunity, phytoalexins

\section{INTRODUCTION}

Grapevine plant (Vitis vinifera) has a surveillance system considered as the first defense line against invader pathogens, activated after signal molecule perception. These molecules may come from infectious agents or non-pathogenic microorganisms and therefore be designated as pathogen- or microbeassociated molecular patterns (PAMPs or MAMPs), respectively; they may correspond also to secondary products released during pathogen invasion, called damage-associated molecular patterns (DAMPs) (Boller and Felix, 2009; Dodds and Rathjen, 2010). These elicitors are perceived by pattern-recognition receptors, leading to the regulation of plant immunity known as MAMP-triggered immunity (MTI) (Nürnberger and Brunner, 2002; Boller and Felix, 2009), which is often characterized by rapid events occurring within the first minutes to few hours. For example, protein phosphorylation and de-phosphorylation generate diverse defense signaling events, as the triggering of mitogen activated protein kinases (MAPKs) and the modification of plasma membrane permeability (Romeis, 2001). In particular, the influx of extracellular $\mathrm{Ca}^{2+}$ causes specific variations of free cytosolic calcium concentrations $\left(\left[\mathrm{Ca}^{2+}\right]_{\text {cyt }}\right.$ ) into elicited cells, considered cardinal for defense response activation (Lecourieux et al., 2002; Vandelle et al., 2006). In addition, reactive oxygen species (ROS), which may have direct toxic effect on the pathogen, are produced. Depending on the host and the elicitor, these signals lead to specific transcriptional and metabolic modulations (Romeis, 2001; Garcia-Brugger et al., 2006), e.g., the synthesis of antimicrobial secondary metabolites as phytoalexins, and pathogenesis related (PR)-proteins as $\beta-1,3$ glucanases and chitinases (Garcia-Brugger et al., 2006; Van Loon et al., 2006). Key signal molecules such as salicylic acid (SA) and jasmonic acid (JA) are also produced within hours after elicitor perception and participate in the regulation of downstream defense genes (Robert-Seilaniantz et al., 2011). The stimulation prior infection of these defense responses confers a protection to the whole plant, thus might be considered as a 
durable and acceptable alternative to pesticide application in grapevine disease management (Ippolito and Sanzani, 2011). In fact, grapevine is highly susceptible to various diseases including downy mildew caused by Plasmopara viticola and gray mold caused by Botrytis cinerea, both diseases are responsible for yield and quality losses in most of the world's vineyards (Sanzani et al., 2012).

The efficiency and mode of action of several elicitors in triggering grapevine defense responses have been extensively studied. Bacterial elicitors, such as harpin and flagellin, proved to stimulate grapevine innate immunity through early signaling event activation and defense gene induction (Qiao et al., 2010; Chang and Nick, 2012; Trdá et al., 2014). Similarly, various fungal elicitors, such as chitin derivatives and endopolygalacturonase1 from $B$. cinerea (BcPG1), proved to enhance efficiently grapevine defense responses (Poinssot et al., 2003; Aziz et al., 2006; Vandelle et al., 2006). Finally, the $\beta$-glucan laminarin, even in its sulphated form, proved to induce various defense events in grapevine cell suspensions, including calcium influx, oxidative burst, activation of MAPKs, defense gene expression, and phytoalexin accumulation, providing protection of grapevine plantlets against downy mildew and gray mold (Aziz et al., 2003; Trouvelot et al., 2008; Gauthier et al., 2014). In particular, the main grapevine phytoalexin resveratrol has a well-known antifungal activity against grapevine pathogens by inhibiting the conidia germination and mycelial growth (Adrian et al., 1997, 2012; Aziz et al., 2003).

However, elicitors applied in the field often provide highly variable protection, probably related to their composition and the complex environment/plant/pathogen interactions (Adrian et al., 2012; Delaunois et al., 2013). Nevertheless, activation of the plant immune system prior infection remains a promising approach, which needs improvement of elicitor effectiveness, investigation of new molecules and deep knowledge of their mode of action (Caillot et al., 2012).

In the past two decades, increasing attention has been paid to the bioactive role of protein hydrolysates manufactured from various sources (Clemente, 2000). Protein hydrolysates contain a wide variety of active peptides with low molecular weight, which directly influence numerous biological processes evoking hormonal and immunological responses (Phelan et al., 2009). At present, hydrolysates manufactured from milk proteins, as casein, and leguminous plants, as soybean, are widely investigated as natural antioxidant compounds, and have interesting applications as supplements in food and pharmaceutical preparations with antimicrobial properties (Gibbs et al., 2003; Kumar et al., 2013). Besides, they proved to be as effective as a commercial repellent in preventing animals from browsing trees and shrubs (Kimball and Nolte, 2006). Finally, protein hydrolysates proved to act as biostimulants on corn (Zea mays), dwarf pea (Pisum sativum), and tomato (Solanum lycopersicum) (Colla et al., 2014). In previous studies, Lachhab et al. (2014, in press) reported the efficacy of soybean and casein hydrolysates in controlling gray mold of grape berries and green mold of citrus fruit. Both hydrolysates, at the tested concentrations $(\geq 1.6 \mathrm{mg} / \mathrm{ml})$, did not show any direct effect on the pathogen growth. These results urged us to investigate further the ability of both hydrolysates to act as elicitors of plant immunity. Therefore, a study on grapevine cell suspensions was conducted with respect to plant early signaling events, as oxidative burst, $\left[\mathrm{Ca}^{2+}\right]_{\mathrm{cyt}}$ variations, MAPK activation, expression of defense-related genes, and phytoalexin accumulation. The protective effect of these hydrolysates against $P$. viticola was also tested on grapevine leaves.

\section{MATERIALS AND METHODS PLANT AND CELL CULTURE MATERIALS}

Grapevine plantlets ( $V$. vinifera cv. Marselan) susceptible to $P$. viticola, were grown in glasshouse conditions, as described by Gauthier et al. (2014). Wild-type and apoaequorin-transformed grapevine cells ( $V$. vinifera cv. Gamay) were cultivated as described by Vandelle et al. (2006).

\section{ELICITOR PREPARATION}

Protein hydrolysates, from soybean (soy) and casein (cas), produced for the pharmaceutical and food industry were supplied by "A. Costantino \& C. S.p.A." (Favria, Turin, Italy). Since the two products are not yet on the market and protected by a trademark, their physicochemical characteristics cannot be reported. Solutions at $1.6 \mathrm{mg} / \mathrm{ml}$ in sterile ultra-pure or distilled water were prepared $24 \mathrm{~h}$ before use, $0.20 \mu \mathrm{m}$ filtered and stored at $4^{\circ} \mathrm{C}$. This concentration was selected based on previous trials (Lachhab et al., 2014, in press). Oligogalacturonides (OG) were provided by Goëmar laboratories (Saint-Malo, France).

\section{PLANT TREATMENT AND INOCULATION}

Both faces of leaves of 8 -weeks old grapevine plantlets were sprayed by soy and cas hydrolysates. A volume of $10 \mathrm{ml}$ per plant was used. Plant treated by water served as a control. For inoculation, $P$. viticola sporangia were collected from sporulating leaves and suspended in distilled water at a concentration of $10^{4}$ sporan$\mathrm{gia} / \mathrm{ml}$. Inoculation was performed by spraying a freshly prepared sporangia suspension onto the abaxial face of leaves $24 \mathrm{~h}$ post treatment (hpt). Plants were placed for $5 \mathrm{~h}$ in a humid chamber $\left(100 \%\right.$ relative humidity, $24 \pm 2{ }^{\circ} \mathrm{C}$ ), and then transferred back to the greenhouse. Five days post inoculation (dpi), plants were placed again in the humid chamber overnight to stimulate sporulation. Disease was assessed estimating the leaf surface area $(\%)$ covered by sporulation. Five plants were used per condition, evaluating three leaves per plant that were marked before treatment.

\section{CELL PREPARATION FOR TREATMENTS}

To investigate early signaling events (ROS, $\mathrm{Ca}^{2+}$ and MAPK), cells were transferred in the M10 buffer (10 mM MES, $175 \mathrm{mM}$ mannitol, $\left.0.5 \mathrm{mM} \mathrm{K}_{2} \mathrm{SO}_{4}, 0.5 \mathrm{mM} \mathrm{CaCl}_{2} ; \mathrm{pH} 5.3\right)$, re-suspended at $0.1 \mathrm{~g}$ of fresh weight of cells (FWC) per $\mathrm{ml}$ and equilibrated for $1 \mathrm{~h}$ in light $\left(130 \mathrm{rpm}\right.$ at $\left.24^{\circ} \mathrm{C}\right)$ before treatments (Trdá et al., 2014). For phytoalexin and gene expression analyses, they were aseptically subcultured and equilibrated at the exponential growth phase $12 \mathrm{~h}$ before elicitation. In each analysis, cell suspensions were treated with $1.6 \mathrm{mg} / \mathrm{ml}$ soy or cas. Water and $0.5 \mathrm{mg} / \mathrm{ml}$ OG served as negative and positive control, respectively. 


\section{ANALYSIS OF THE VARIATIONS IN FREE CYTOSOLIC CALCIUM CONCENTRATION $\left(\left[\mathrm{Ca}^{2+}\right]_{\text {cyt }}\right)$}

Variations in $\left[\mathrm{Ca}^{2+}\right]_{\text {cyt }}$ were analyzed following aequorin bioluminescence of $250 \mu \mathrm{l}$ of apoaequorin-expressing cells using a luminometer (Lumat LB9507, Berthold Technologies, Bad Wildbad, Germany) as described in Dubreuil-Maurizi et al. (2010) with minor modifications. In vivo reconstitution of aequorin was performed adding $5 \mu \mathrm{l}$ of coelenterazine $(5 \mathrm{mM}$ stock solution in DMSO) to $5 \mathrm{ml}$ of aequorin-transformed cell suspension for at least $3 \mathrm{~h}$ in the dark. Aequorin was quantified adding $300 \mu \mathrm{l}$ of lysis buffer $\left(2 \mathrm{M} \mathrm{CaCl}_{2} ; 20 \%\right.$ ethanol, $\mathrm{v} / \mathrm{v})$. Finally, variations in $\left[\mathrm{Ca}^{2+}\right]_{\text {cyt }}$ were calculated following the calibration equation developed by Rentel and Knight (2004).

\section{$\mathrm{H}_{2} \mathrm{O}_{2}$ PRODUCTION MEASUREMENT}

$\mathrm{H}_{2} \mathrm{O}_{2}$ production was determined using chemiluminescence of luminol as described in Gauthier et al. (2014). Briefly, aliquots $(250 \mu \mathrm{l})$ of cell suspension were added with $300 \mu \mathrm{l}$ of $\mathrm{H} 50$ medium ( $50 \mathrm{mM}$ Hepes, $175 \mathrm{mM}$ mannitol, $5 \mathrm{mM} \mathrm{CaCl}_{2}, 0.5 \mathrm{mM}$ $\mathrm{K}_{2} \mathrm{SO}_{4} ; \mathrm{pH} 8.5$ ) and $50 \mu \mathrm{l}$ of $0.3 \mathrm{mM}$ luminol. Relative luminescence was recorded within a 10 -s period using a luminometer (Lumat LB 9507, Berthold Technologies, Bad Wildbad, Germany) and expressed as nmol $\mathrm{H}_{2} \mathrm{O}_{2}$ per gram of FWC.

\section{WESTERN BLOT ANALYSES}

Western blot analyses were performed as described by Trdá et al. (2014). Aliquots containing $15 \mu \mathrm{g}$ of protein were solubilised in a buffer (Laemmli, 1970) and submitted to $10 \%$ SDS-PAGE, before transfer to nitrocellulose membrane (Hybond ECL, Amersham Biosciences, Munchen, Germany) for western blotting. Phosphorylated MAPKs were detected with an antibody raised against a synthetic phospho-Thr202/Tyr204 peptide of human phosphorylated extracellular regulated protein kinase $1 / 2$ ( $\alpha$-pERK1/2, Cell Signaling, Danvers, MA, USA). Probing and detection were performed by an ECL Western detection kit (Amersham Biosciences, Little Chalfont, UK).

\section{CELL DEATH IN GRAPEVINE CELL SUSPENSIONS}

Dead cells were quantified according to Binet et al. (2001). Briefly, $24 \mathrm{~h}$ post treatment (hpt), cells were incubated $15 \mathrm{~min}$ with the vital neutral red dye $0.01 \%$, and then washed extensively with buffer M10 ( $\mathrm{pH} \mathrm{7)}$ to remove excess dye. A colorless vacuole assessed by microscope observation was considered as measure of cell death.

\section{GENE EXPRESSION BY REAL-TIME QUANTITATIVE PCR (qPCR) ANALYSES}

Aliquots $(2 \mathrm{ml})$ of treated cells were harvested by filtration on GF/A filters following a time course $(0,4,8,12,24,36,48$, and $72 \mathrm{hpt}$ ), frozen and ground in liquid nitrogen. Total RNA isolation was obtained by Trizol (Sigma-Aldrich, St. Louis, MO, USA). The RNA yield and quality were determined by NanoDrop 2000 (Thermo Scientific, Waltham, MA, USA). cDNAs were synthesized by reverse-transcribing $400 \mathrm{ng}$ of total RNA using Superscript III reverse transcriptase kit (Life Technologies, Saint Aubin, France). Amplifications were run in a 96 well-plates iCycler iQ thermal cycler (BioRad, Hercules, CA, USA) and quantification was performed with the iCycler iQTM associated software
(Real time Detection System Software, version 3.0). Differential expression was determined according to the $2^{-\Delta \Delta \mathrm{Ct}}$ method (Livak and Schmittgen, 2001). Elongation factor EF1 $\gamma$ was used as a reference gene (Dufour et al., 2013). The sequences of the primer pairs used are reported in Table S1. Reaction conditions were those reported by Dubreuil-Maurizi et al. (2010). Each reaction was performed in $20 \mu \mathrm{l}$-volume containing $10 \mu \mathrm{l}$ SsoAdvanced SYBR Green Supermix (BioRad), $0.5 \mu \mathrm{l}(500 \mathrm{nM})$ of each primer, $1 \mu \mathrm{l}$ of nuclease-free water and $8 \mu \mathrm{l}$ cDNA (diluted 40 -fold). For each primer pair, previously, calibration curves were built up amplifying cDNAs synthesized from serial dilutions (from 1 to $1000 \mathrm{ng}$ ) of total RNA. Linear equations, determination coefficients $\left(R^{2}\right)$ and reaction efficiencies were calculated.

$\mathrm{Ct}$ values and RNA concentrations proved to be linearly correlated with determination coefficients $\left(\mathrm{R}^{2}\right)$ ranging from 0.94 to 0.99 (Table S2). Reaction efficiencies were similar to that of the housekeeping EF1 $\gamma$ gene and included in the optimal range $90-110 \%$.

\section{PHYTOALEXIN QUANTIFICATION}

After cell treatments, phytoalexins were quantified in two different fractions (cells/culture medium) separated by filtration on GF/A filters following the same time course of qPCR analyses. The culture medium samples were directly analyzed, whereas cell samples were stirred vigorously and incubated in $2 \mathrm{ml}$ absolute ethanol for $24 \mathrm{~h}$ at $4^{\circ} \mathrm{C}$ to extract stilbenes. Samples were analyzed by an Acquity UPLC system (Waters, Milford, MA, USA) equipped with a model 2996 photo-diode array detector, as described by Boutegrabet et al. (2011). Each sample (10 $\mu \mathrm{l})$ was loaded onto a BEH C18 column (Waters, Eschborn, Germany) equilibrated with water-acetonitrile-formic acid 100:10:0.1 (v/v) (Solvent A) and acetonitrile (Solvent B). Stilbenes were eluted with a stepwise gradient as follows: $0 \%$ B (0-1.73 $\mathrm{min}), 16 \%$ B (1.73-2.73 min), 42\% B (2.73-4.12 min), 0\% B (5-6 min) at a flow rate of $0.8 \mathrm{ml} / \mathrm{min}$. Quantification of stilbenes was performed by calibration curves, using the peak area of different amounts of standards detected at $305 \mathrm{~nm}$ and $320 \mathrm{~nm}$, and the chromatographic characteristics were calculated using Waters Empower software.

\section{STATISTICAL ANALYSES}

When more than two conditions were present (water control, soy and cas), data were subjected to ANOVA (One-Way analysis of variance). Significant differences $(P \leq 0.05)$ were identified by the General Linear Model (GLM) procedure with the Duncan's Multiple Range Test (DMRT). Percentage data of incidence of decay underwent arcsine-square-root transformation before ANOVA analysis. For gene expression data, since just two conditions were compared (relative expression by soy and cas), Student's $t$-test was applied. Data were processed using the software package Statistics for Windows (StatSoft, Tulsa, OK, USA).

\section{RESULTS \\ SOYBEAN AND CASEIN HYDROLYSATES INDUCE GRAPEVINE RESISTANCE AGAINST $P$. VITICOLA}

To evaluate the resistance of hydrolysates-treated grapevine plants to downy mildew, a first dose-response experiment has been 
realized with $0,0.4,0.8$ and $1.6 \mathrm{mg} / \mathrm{ml}$. Results indicated that only the $1.6 \mathrm{mg} / \mathrm{ml}$ concentration gave a reproducible plant protection against $P$. viticola (data not shown). Thereafter, plants were sprayed by soy and cas at $1.6 \mathrm{mg} / \mathrm{ml}$, inoculated by $P$. viticola sporangia $24 \mathrm{~h}$ later and evaluated for the leaf sporulating area at $5 \mathrm{dpi}$. A significant reduction of disease severity by $76 \%$ for soy and $63 \%$ for cas was observed as compared to the control. However, no difference was found between the two hydrolysates (Figure 1).

\section{EFFECT OF SOYBEAN AND CASEIN HYDROLYSATES ON EARLY SIGNALING EVENTS}

To investigate whether soy and cas have the ability to act as efficient elicitors of grapevine immune responses, we characterized the early signaling events known to be triggered upon elicitor perception in cell suspensions.

Given the pivotal role of $\mathrm{Ca}^{2+}$ in transducing the signal and activating the plant surveillance system against pathogen invasion, we investigated $\left[\mathrm{Ca}^{2+}\right]_{\text {cyt }}$ variation in elicited aequorinexpressing cells. Soy and cas derived peptides caused a transient increase in $\left[\mathrm{Ca}^{2+}\right]_{c y t}$ with different signature in peak time and trend (Figures 2A,B). Although of similar intensity (Figure 2D), OG triggered a biphasic increase of $\left[\mathrm{Ca}^{2+}\right]_{\text {cyt }}$ in cells (Figure 2C).

Soy induced a rapid increase of $\left[\mathrm{Ca}^{2+}\right]_{\mathrm{cyt}}$ after $40 \mathrm{~s}$, peaked after $2 \mathrm{~min}$, to decrease slowly without returning to the background level after $15 \mathrm{~min}$ as compared to $\mathrm{OG}$ and water (Figure 2A). Whereas in cas-treated cells, the level of $\left[\mathrm{Ca}^{2+}\right]_{c y t}$ increased $1 \mathrm{~min}$ after treatment and picked at $4.5 \mathrm{~min}$. Thereafter, $\left[\mathrm{Ca}^{2+}\right]_{\text {cyt }}$ returned to the basal level (Figure 2B) within $10 \mathrm{~min}$. When cells were treated with $\mathrm{OG}$, the maximum of $\left[\mathrm{Ca}^{2+}\right]_{\text {cyt }}$ was recorded at the first peak after $2 \mathrm{~min}$, then decreased to sign the second peak at $4 \mathrm{~min}$ and turned back to the basal level as in cas-treated cells (Figure 2C).

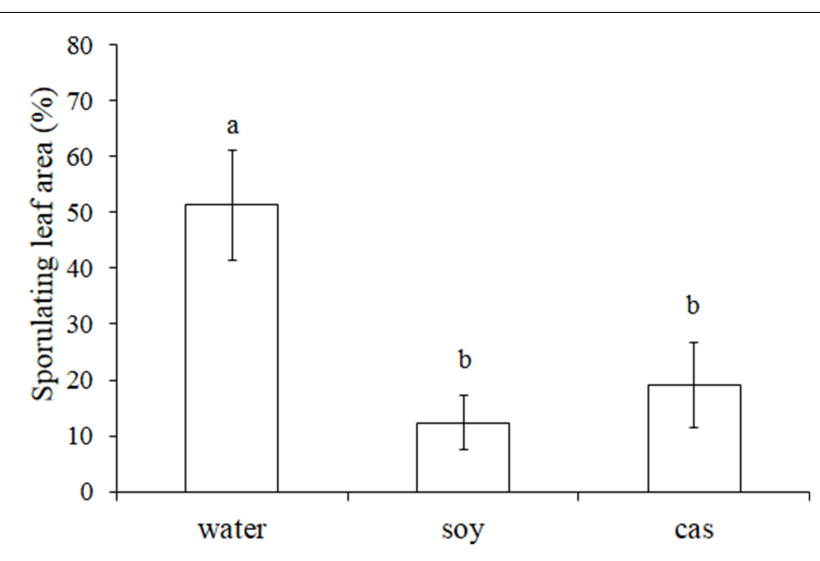

FIGURE 1 | Soybean (soy) and casein (cas) hydrolysates induce resistance of grapevine against Plasmopara viticola. Plantlets were sprayed with water, soy or cas $(1.6 \mathrm{mg} / \mathrm{ml}) 24 \mathrm{~h}$ before $P$. viticola inoculation $\left(10^{4}\right.$ spores $\left./ \mathrm{ml}\right)$. Leaf sporulating area $(\%)$ was evaluated at 5 DPI. Data represent means \pm standard deviation from 3 leaves of 5 independent plants per modality $(n=15)$. Results are from one representative experiment out of 3 repetitions with similar results. Significant differences $(P \leq 0.05)$ were identified with the Duncan's Multiple Range Test. Bars with different letters are significantly different.
MAPK phosphorylation was investigated by immunoblotting protein extracts from hydrolysate-treated cells with polyclonal antibodies that specifically react with the phosphorylated form of plant ERK-related activated MAPKs. Soy and cas showed ability to strongly activate two phosphorylated MAPK orthologs with molecular masses of 45 and $49 \mathrm{kDa}$ (Figures 2E,F). In treated cells, the activation of protein kinases peaked after 15-30 min, and remained until $90 \mathrm{~min}$ in soy-treated cells (Figure 2E), whereas in cas-treated cells returned almost to the basal level within $60 \mathrm{~min}$ (Figure 2F).

Generation of $\mathrm{H}_{2} \mathrm{O}_{2}$ in cells treated with soy or cas was determined using a luminol chemiluminescence assay. A basal $\mathrm{H}_{2} \mathrm{O}_{2}$ production was observed in control cells. The addition of $\mathrm{OG}$ to grapevine cells led to a rapid $\mathrm{H}_{2} \mathrm{O}_{2}$ production, whereas soy and cas did not cause any significant oxidative burst (data not shown).

The toxicity of soy and cas hydrolysates was also evaluated by cell viability assays, in which the number of red colored grapevine cells was assessed at $24 \mathrm{hpt}$. We did not recorded any toxic effect of the two hydrolysates compared to the water control (data not shown).

\section{SOYBEAN AND CASEIN HYDROLYSATES INDUCE DEFENSE-RELATED GENE EXPRESSION IN GRAPEVINE CELL SUSPENSIONS}

In this study we evaluated by qPCR in time-course experiments the expression in grapevine cell suspensions of six selected defense genes known to be activated in response to various elicitors: those encoding a pathogenesis-related protein 1 (PR1), a B1,3-glucanase $(P R 2)$, a chitinase $4 c(P R 3)$, a protease inhibitor $(P R 6)$, a polygalacturonase-inhibiting protein $(P G I P)$ and a stilbene synthase (STS). Overall, soy and cas induced a rapid and high transcript accumulation of most of the tested genes with different kinetics and intensities; a more pronounced effect of soy was generally observed (Figure 3). With the exception of PR1, whose transcript accumulation was up-regulated late in both hydrolysate-treated cells, the expression pattern of genes encoding the antifungal proteins $P R 2$ and $P R 3$ were similar in grapevine cells treated with both hydrolysates, with rapid and massive accumulation of PR3 transcripts in soy-elicited cells, which reached a 534-fold increase at $8 \mathrm{hpt}$. The latter hydrolysate induced a similar accumulation also of PR6, that peaked at 8 hpt by 790 fold, and remained more expressed than in water-treated cells until 72 hpt. When treated with cas, the PR6 expression pattern showed a different trend, reaching the maximum by 24 -fold only at 48 hpt. Concerning PGIP, transcript accumulations was up-regulated even later than $P R 1$ in both hydrolysate-treated cells, being more pronounced in soy-treated cells. Finally, following treatment of the grapevine cell suspensions with the two hydrolysates, the STS gene, encoding a key enzyme of the resveratrol biosynthesis (the main grapevine phytoalexin), showed a biphasic expression profile. It peaked at 4 or $8 \mathrm{hpt}$ for soy- and cas-treated cells, respectively.

\section{SOYBEAN AND CASEIN HYDROLYSATES INDUCE PHYTOALEXIN ACCUMULATION IN GRAPEVINE CELL SUSPENSIONS}

Both protein hydrolysates, in particular those extracted from soybean, showed ability to elicit the production of stilbenes. 

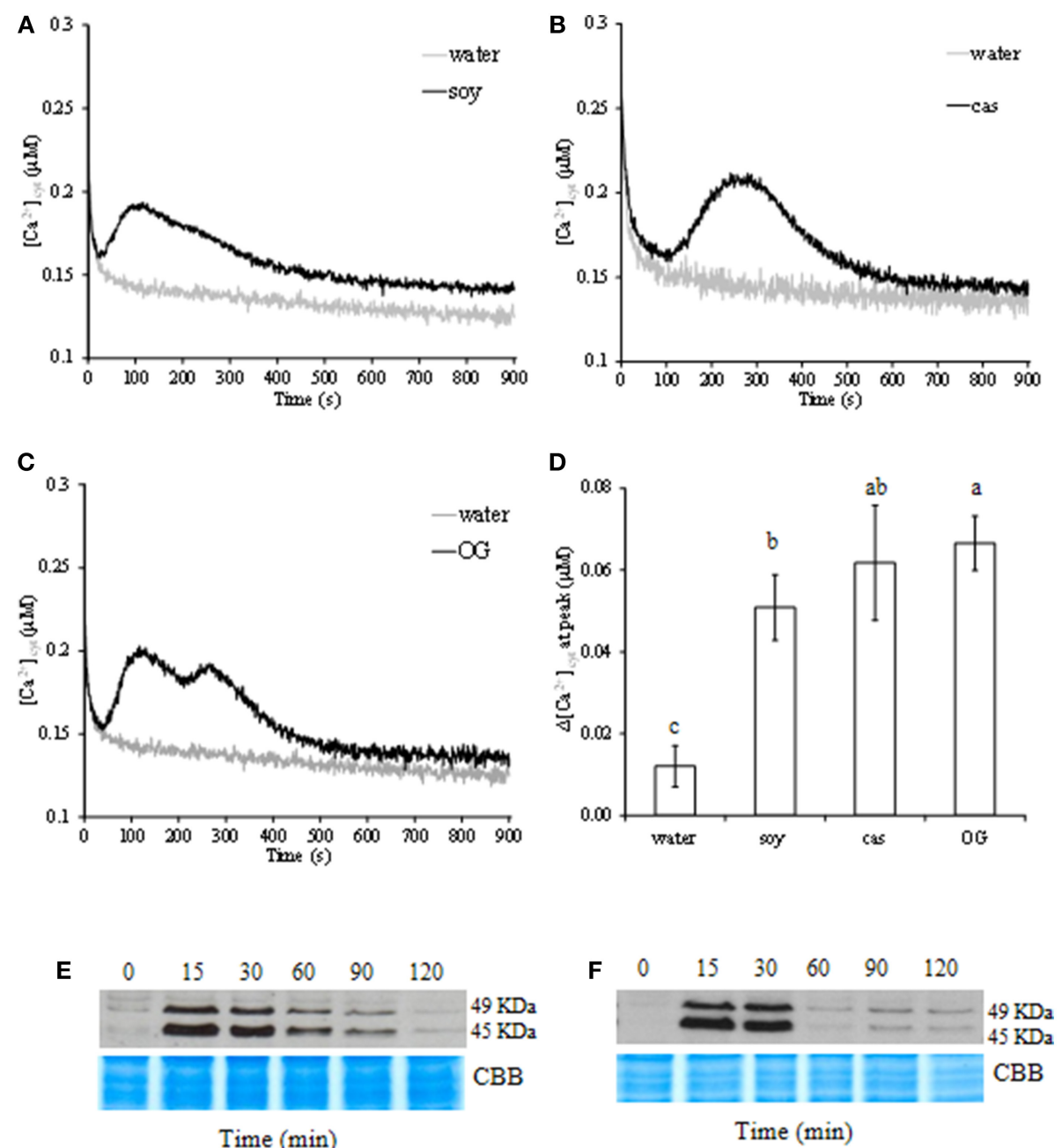

FIGURE 2 | Variations of free cytosolic calcium $\left(\left[\mathrm{Ca}^{2+}\right]_{\text {cyt }}\right)$ concentration in aequorin-expressing cell suspensions elicited by soybean (soy, A) and casein (cas, B) hydrolysate at $1.6 \mathrm{mg} / \mathrm{ml}$, or oligogalacturonide $(\mathrm{OG}, \mathrm{C}$ ) at $\mathbf{0 . 5} \mathbf{~ \mathbf { g }} / \mathbf{m l}$. Results are from one representative experiment out of three independent ones. Quantitative representation of the difference among $\left[\mathrm{Ca}^{2+}\right]_{\text {cyt }}$ peaks (D); data represent means of three independent experiments \pm standard deviation.

Significant differences $(P \leq 0.05)$ were identified with the Duncan's Multiple Range Test. Bars with different letters are significantly different. Phosphorylation kinetics of two mitogen-activated protein kinases (MAPKs) of 49 and $45 \mathrm{kDa}$ in (E) soy- and (F) cas-treated cells. For each treatment, homogeneous protein loading was checked by Coomassie brilliant blue staining (CBB). Results are from one representative experiment out of three.

Concentrations in the culture medium and inside the cells varied at different extents (Figure 4). In particular, a higher accumulation of resveratrol $\left(3,5,4^{\prime}\right.$-trihydroxystilbene) was recorded in the culture medium. It was already detected at $4 \mathrm{hpt}$, significantly increased to reach 97 and $37 \mu \mathrm{g} / \mathrm{g}$ FWC after $8 \mathrm{hpt}$ for soy-and cas-treated cells, respectively, and then decreased to the level of water control at 48-72 hpt (Figure 4A). A similar trend, although with lower values, was observed for resveratrol inside the cells (Figure 4D).

The resveratrol dimers $\delta$ - and $\varepsilon$-viniferin, significantly increased after treatment by the two hydrolysates both in culture medium and inside the cells.

In culture medium of soy-treated cell suspension, $\delta$-viniferin peaked at $8-12 \mathrm{hpt}$, reaching $10 \mu \mathrm{g} / \mathrm{g}$ FWC (Figure 4B), whereas $\varepsilon$-viniferin reached the maximum level at $24 \mathrm{hpt}(2.37 \mu \mathrm{g} / \mathrm{g}$ FWC;
Figure 4C). A less pronounced accumulation of $\delta$-viniferin and $\varepsilon$-viniferin in the culture medium was recorded in the cas-treated cell suspension, peaking at $24 \mathrm{hpt}$ (Figures 4B,C).

In cells elicited by soy, $\delta$ - and $\varepsilon$ - viniferin peaked at 12 or $24 \mathrm{hpt}$ with values of 6 and $2.3 \mu \mathrm{g} / \mathrm{g}$ FWC, respectively. In cells elicited by cas the two resveratrol dimers showed a low increase at 24 and $48 \mathrm{hpt}$, with values of 1.9 and $1.4 \mu \mathrm{g} / \mathrm{g}$ FWC, respectively (Figures 4E,F).

The resveratrol glucoside piceid was not significantly accumulated in hydrolysate-treated cells and culture medium as compared to the water control (data not shown).

\section{DISCUSSION}

On the bases of the effectiveness of soy and cas hydrolysates to trigger resistance against gray and green mold (Lachhab et al., 

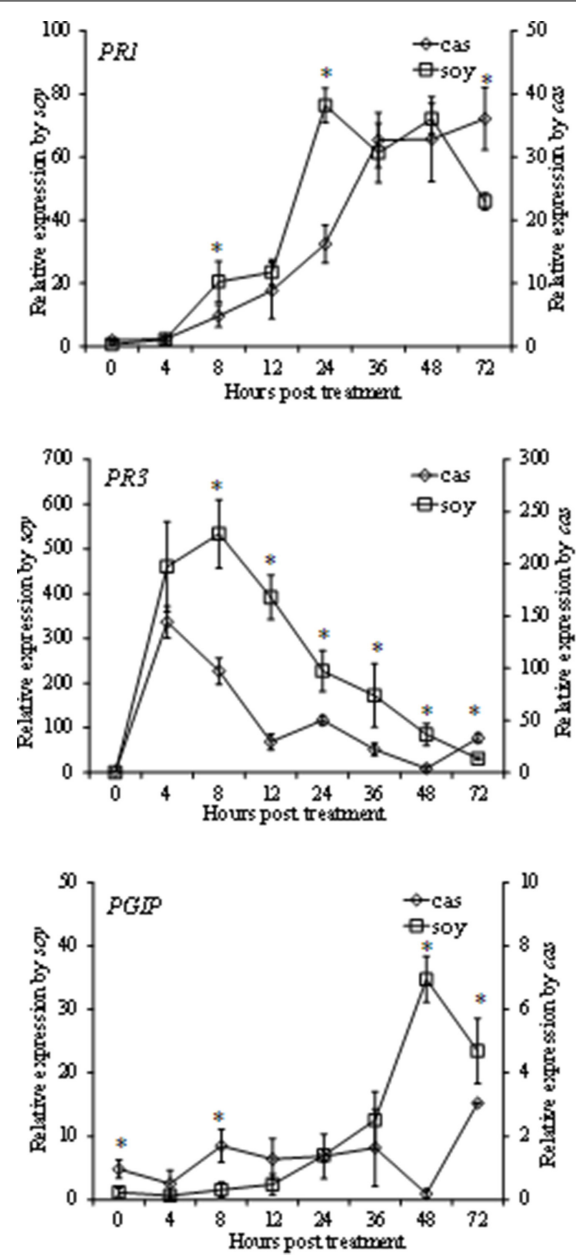

FIGURE 3 | Relative expression kinetics in grapevine cells elicited by soybean (soy) and casein (cas) hydrolysates at $1.6 \mathrm{mg} / \mathrm{ml}$ of 6 defense related genes encoding: pathogenesis-related protein 1 (PR1), B-1,3-glucanase (PR2), chitinase 4c (PR3), protease inhibitor $(P R 6)$, polygalacturonase-inhibiting protein (PGIP) and stilbene synthase (STS). Cell samples were collected at $0,4,8,12,24,36,48$, $72 \mathrm{~h}$ post treatment. Water-treated cells were used as a control. Data were analyzed with the $2^{-\Delta \Delta C t}$ method using data of water treated cells
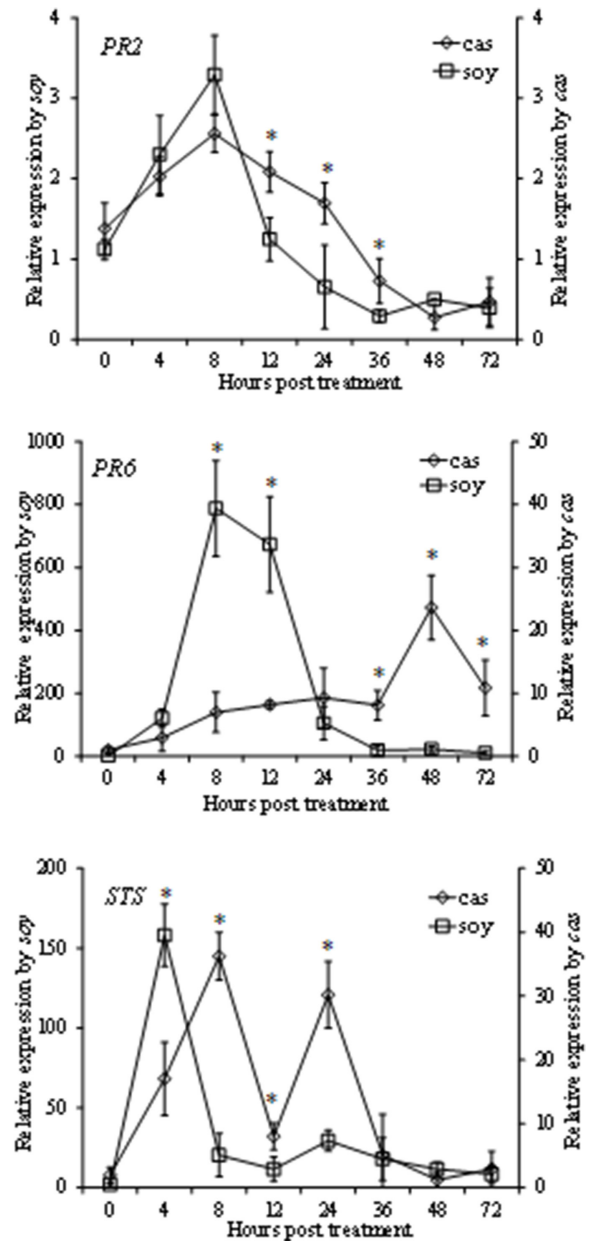

as a control, and normalized using the EF1 $\gamma$ housekeeping gene. Data represent the means of three experiments \pm standard deviation. Statistical significances $(P \leq 0.05)$ were determined using Student's $t$-test using paired data. ${ }^{*}$ indicates significant differences between treatments. Since, in presence of the two treatments, highly different expression extents were recorded for most of the genes, two Y-axes were used in the graphs. Relative expression values in presence of each treatment refer to the respective axis.
2014, in press) and downy mildew (this study) without any effect on the growth in vitro of the different pathogens (Lachhab et al., 2014, in press), we hypothesized that the two hydrolysates might act as general elicitors. They could trigger signaling events involved in grapevine immunity as already reported elsewhere for other elicitor molecules (Aziz et al., 2003, 2007; Poinssot et al., 2003; Trouvelot et al., 2008; Gauthier et al., 2014; Trdá et al., 2014). Therefore, we investigated their effect on grapevine cells with respect to $\left[\mathrm{Ca}^{2+}\right]_{\text {cyt }}$ variations, $\mathrm{H}_{2} \mathrm{O}_{2}$ production, MAPK activation, defense genes expression, and phytoalexin production. Both soy and cas induced specific changes of $\left[\mathrm{Ca}^{2+}\right]_{c y t}$, considered essential for defense response activation (Lecourieux et al., 2002; Tuteja, 2009). In particular, cells elicited by the two hydrolysates showed a rapid increase of $\left[\mathrm{Ca}^{2+}\right]_{\mathrm{cyt}}$, as compared to water control, similarly to other elicitors as OG, cryptogein, BcPG1, and Flg 22 (Lecourieux et al., 2006; Vandelle et al.,
2006; Aziz et al., 2007; Trdá et al., 2014). However, soy and cas showed two specific signatures, characterized by different kinetics and duration, suggesting different active molecules in each hydrolysate (Blume et al., 2000; Knight, 2000; Lecourieux et al., 2006). In fact, in soy-treated cells, the increase in $\left[\mathrm{Ca}^{2+}\right]_{\text {cyt }}$ was more rapid than that triggered by cas, and the level of free cytosolic calcium remained higher as compared to water and cas treatments. A similar behavior was observed in $\left[\mathrm{Ca}^{2+}\right]_{\mathrm{cyt}}$ signatures induced by the polypeptide cryptogein in tobacco cells (Lecourieux et al., 2006), although it was not observed in response to a range of different oligosaccharide elicitors, including our positive control OG. These findings suggest that the active elicitor molecule in soy is likely not an oligosaccharide as assumed elsewhere (Lachhab et al., in press). The characterization of soy and cas chemical composition by the manufacturer is in progress. 

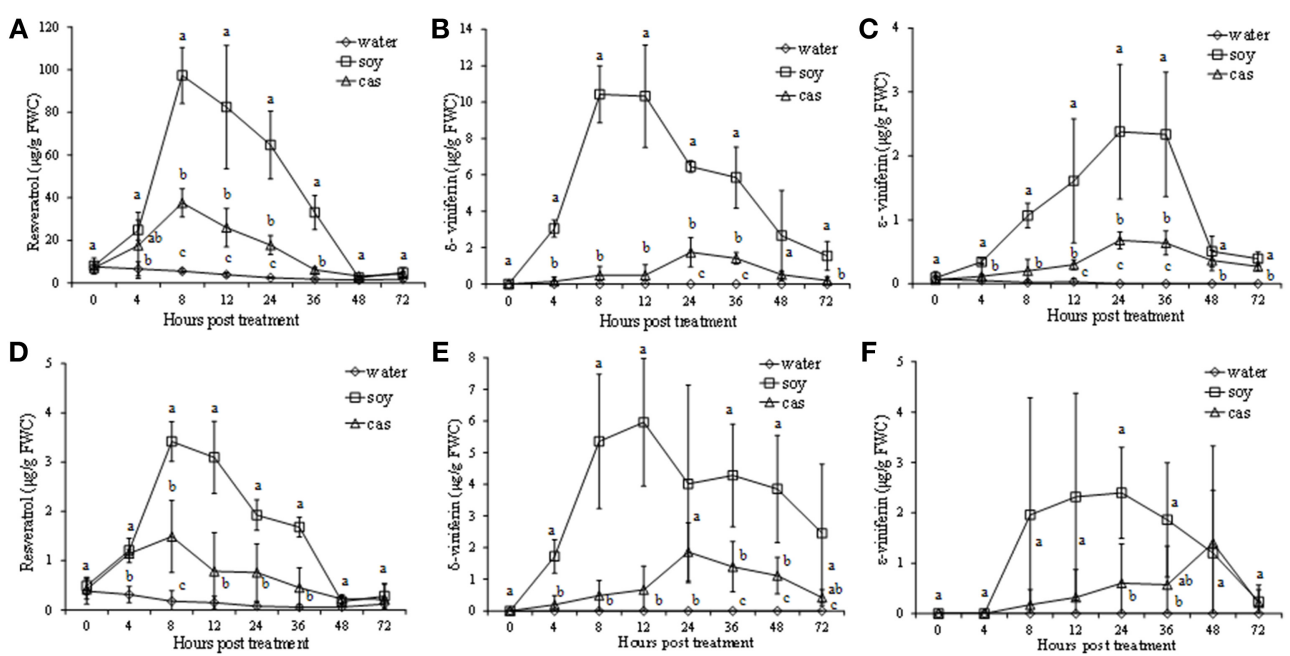

FIGURE 4 | Stilbene production in culture medium (A-C) and grapevine cells (D-F) elicited by soybean (soy) and casein (cas) hydrolysates from 0 to $\mathbf{7 2} \mathrm{h}$ post treatment. Resveratrol $(A, D), \delta$-viniferin $(B, E)$, $\varepsilon$-viniferin $(\mathbf{C}, \mathbf{F})$ amounts were expressed as $\mu \mathrm{g} / \mathrm{g}$ of fresh weight of cells
(FWC). Data represent the mean of three independent experiments \pm standard deviation. Significant differences $(P \leq 0.05)$ were identified with the Duncan's Multiple Range Test. Time-points with different letters are significantly different.
Calcium signaling is known to act upstream of the MAPK pathway in some plant defense responses (Link et al., 2002; Lecourieux et al., 2006). In this study, we showed in soy-treated cells a fast, strong, and lasting MAPK activation, which is consistent with the high level of free cytosolic calcium concentration. These results are similar to those of Lecourieux et al. (2002) who recorded an activation of MAPKs in tobacco cells at $2 \mathrm{~h}$ following cryptogein elicitor application. The relation between $\left[\mathrm{Ca}^{2+}\right]_{\text {cyt }}$ and MAPK stimulation is more evident considering the cas- effect. Indeed, the rapid decrease of the $\left[\mathrm{Ca}^{2+}\right]_{\text {cyt }}$ level is correlated with a very low activation of MAPKs after $60 \mathrm{~min}$, as previously demonstrated in cryptogein-treated tobacco cells (Lecourieux et al., 2002).

In addition to $\left[\mathrm{Ca}^{2+}\right]_{\text {cyt }}$ variations and MAPKs activation, many authors described the rapid release of $\mathrm{H}_{2} \mathrm{O}_{2}$ in cell suspensions as a response to various elicitors (Poinssot et al., 2003; Aziz et al., 2007; Trouvelot et al., 2008). However, soy- and caselicited cells did not show any variation in $\mathrm{H}_{2} \mathrm{O}_{2}$ production. Furthermore, similarly to the $\beta$-glucan derivative PS3, the two hydrolysates did not have any toxic effect on grapevine cells, supporting the hypothesis that the resistance to pathogen invasion may depend on other defense responses rapidly activated during pathogen infection (Aziz et al., 2007; Gauthier et al., 2014). In fact, in some instances, $\mathrm{H}_{2} \mathrm{O}_{2}$ generation is not necessary for the induction of defense reactions. As shown by Galletti et al. (2008), a null mutation of AtrbohD-mediated oxidative burst completely abolished the induction of oxidative burst elicited by OGs in Arabidopsis, without affecting the expression of genes involved in defense responses effective against $B$. cinerea. In addition, Pauw et al. (2004) showed that ROS generation is neither necessary nor sufficient for the induction of genes involved in the terpenoid indole alkaloids biosynthesis by yeast crude extract in Catharanthus roseus.
Consistently with previous reports, the two tested hydrolysates caused an up-regulation of 6 known defense-related genes (Bézier et al., 2002; Aziz et al., 2003, 2007; Trouvelot et al., 2008; Trdá et al., 2014). It has been shown that a better resistance to $P$. viticola of some Vitis species as $V$. riparia, was associated to a more rapid and stronger induction of defense gene expression, as compared to susceptible cultivars, e.g., V. vinifera (Polesani et al., 2010). Among them particularly relevant are those genes encoding enzymes involved in the phenylpropanoid pathway as STS, and PR-proteins (chitinase and $\beta-1,3$ glucanase), whose hydrolytic activities might exert an antimicrobial effect against different pathogens, and that can play themselves a role as elicitors through the release of chitin and glucan oligomers (Fritig et al., 1998; Aziz et al., 2007). In particular, the two hydrolysates elicited marker genes of SA and JA pathways, namely PR1 and PR6 (Lu et al., 2009; Gfeller et al., 2011). In Arabidopsis, SA signaling is classically described to trigger resistance against biotrophic pathogens, whereas JA/ET signaling activates resistance against necrotrophic pathogens (Glazebrook, 2005). Thus, the strong and rapid induction of $P R 6$ is in agreement with the protective effect provided by the two hydrolysates to grapevine against Botrytis attack (Lachhab et al., 2014). Moreover, the two hydrolysates induced the expression of STS the key gene of the biosynthesis of resveratrol, known to increase resistance against pathogens (Coutos-Thévenot et al., 2001; Adrian et al., 2012), e.g., controlling conidia germination and mycelial growth in Phomopsis viticola and $B$. cinerea and affecting $P$. viticola zoospore mobility (Adrian et al., 1997; Pezet et al., 2003).

As expected, the two protein hydrolysates, in particular soy, induced a high and rapid accumulation of resveratrol at $4 \mathrm{hpt}$, the first time-assessment in our trials, meaning that STS gene was induced even before. This finding is in agreement with the concept that stilbene is the primary inducible response of grapevine 
against a number of biotic and abiotic stresses (Adrian et al., 1997; Coutos-Thévenot et al., 2001; Poinssot et al., 2003).

Interestingly, resveratrol was present at high amounts in culture medium, but showed low accumulation in cells. As suggested by Adrian et al. (2012), part of the cell-excreted resveratrol is cross-linked to the cell wall, contributing to cell strengthening.

The $\delta$ - and $\varepsilon$-viniferin dimers, considered as important markers for resistance of grapevine to pathogens (Malacarne et al., 2011), were detected later, as compared to resveratrol, both in culture medium and inside the cells, which is in accordance with the role of resveratrol as a precursor of viniferins. In particular, $\delta$ viniferin more strongly accumulated, as compared to $\varepsilon$-viniferin, in soybean treated cells at $8-12 \mathrm{hpt}$. The $\delta$-viniferin was reported to play an important role in resistance against downy mildew and inhibit the zoospore mobility and mycelium development of P. viticola (Pezet et al., 2004). Indeed, resistant cultivars synthesize high levels of resveratrol after infection, which is rapidly oxidized to yield highly toxic viniferins (Pezet et al., 2004). The success rate of elicitor molecules in inducing plant resistance depends on the coordination between the different triggered defensive events, but also on the rapidity of their activation, that hang on the complex plant/elicitor/pathogen interaction (Giannakis et al., 1998). In this study, soy showed pronounced efficiency in inducing defense responses, as compared to cas treatment, in particular concerning stilbene accumulation. The different results may be ascribed to their different proteic origins. Indeed, soybean contains different proteins as lipid transfer proteins (Kido et al., 2010) and proved to be effective against gray mold also on strawberries (Romanazzi et al., 2013). Casein has an antioxidant activity and the ability to enhance calcium uptake, by forming soluble phosphopeptides activating cell receptors (Gobetti et al., 2004) and stimulating the defenses against bacteria, yeast and filamentous fungi (Fadaei, 2012). However, to better understand the mode of action of these hydrolysates, an investigation of the large number of peptides present in each hydrolysate is needed. Moreover, further specific trials are ongoing to evaluate their stability and effectiveness in the field against $P$. viticola.

In conclusion, the presented data support the use of cas and particularly soy hydrolysates as enhancers of grapevine innate immunity and thus good candidates to replace or reduce fungicide applications in modern sustainable viticulture, as they are cheap, easily available and safe to humans and the environment.

\section{AUTHOR CONTRIBUTIONS}

Nihed Lachhab: conducted the experiments, analyzed data and prepared the manuscript; Simona M. Sanzani: designed the experiments, analyzed the data and prepared the manuscript; Marielle Adrian: supervised phytoalexin quantification, analyzed the data and edited the manuscript; Annick Chiltz and Suzanne Balacey: helped in conducting the experiments; Maurizio Boselli: helped to design the experiments and edited the manuscript; Antonio Ippolito: helped to design the experiments and edited the manuscript; Benoit Poinssot: designed the experiments, analyzed the data and prepared the manuscript. All authors have read the manuscript and agree with its content.

\section{ACKNOWLEDGMENTS}

Nihed Lachhab, Simona M. Sanzani, Maurizio Boselli and Antonio Ippolito are supported by the project « Thirsty Grapes 》 funded by Regione Veneto (PSR 2007-2013, mis. 124, n. 2307790) and the project « ECO_P4 》 funded by Regione Puglia (PON02_00186_2866121). Marielle Adrian, Annick Chiltz, Suzanne Balacey, and Benoit Poinssot are supported by the Conseil Régional de Bourgogne. We acknowledge "A. Costantino \& C. S.p.A.” (Favria, Turin, Italy) for providing the hydrolysates and Agnès Klinguer, Franck Paris, Lucie Trdá, Xavier Daire, Daphnée Brulé and Camille Lesquir for excellent technical assistance.

\section{SUPPLEMENTARY MATERIAL}

The Supplementary Material for this article can be found online at: http://www.frontiersin.org/journal/10.3389/fpls.2014. 00716/abstract

\section{REFERENCES}

Adrian, M., Jeandet, P., Veneau, J., Weston, L. A., and Bessis, R. (1997). Biological activity of resveratrol, a stilbenic compound from grapevines, against Botrytis cinerea, the causal agent for gray mold. J. Chem. Ecol. 23, 1689-1702.

Adrian, M., Trouvelot, S., Gamm, M., Poinssot, B., Héloir, M. C., and Daire, X. (2012). "Activation of grapevine defense mechanisms: theoretical and applied approaches," in Plant Defence: Biological Control, eds J. M. Mérillon, G. Ramawat Kishan (Dordrecht: Springer), 313-331. doi: 10.1007/978-94-0071933-0_13

Aziz, A., Gauthier, A., Bézier, A., Poinssot, B., Joubert, J. M., Pugin, A., et al. (2007). Elicitor and resistance-inducing activities of $\beta$-1,4 cellodextrins in grapevine, comparison with $\beta-1,3$ glucans and $\beta-1,4$ oligogalacturonides. J. Exp. Bot. 58, 1463-1472. doi: 10.1093/jxb/erm008

Aziz, A., Poinssot, B., Daire, X., Adrian, M., Bézier, A., Lambert, B., et al. (2003). Laminarin elicits defense responses in grapevine and induces protection against Botrytis cinerea and Plasmopara viticola. Mol. Plant. Microbe Interact. 16, 1118-1128. doi: 10.1094/MPMI.2003.16.12.1118

Aziz, A., Trotel-Aziz, P., Dhuicq, L., Jeandet, P., Couderchet, M., and Vernet, G. (2006). Chitosan oligomers and copper sulfate induce grapevine defence reactions and resistance to gray mold and downy mildew. Phytopathol 96, 1188-1194. doi: 10.1094/PHYTO-96-1188

Bézier, A., Lambert, B., and Baillieul, F. (2002). Study of defense-related gene expression in grapevine leaves infected with Botrytis cinerea. Eur. J. Plant Pathol. 108, 111-120. doi: 10.1023/A:1015061108045

Binet, M. N., Humbert, C., Lecourieux, D., Vantard, M., and Pugin, A. (2001). Disruption of microtubular cytoskeleton induced by cryptogein, an elicitor of hypersensitive response in tobacco cells. Plant Physiol. 125, 564-572. doi: 10.1104/pp.125.2.564

Blume, B., Nürnberger, T., Nass, N., and Scheel, D. (2000). Receptor-mediated increase in cytoplasmic free calcium required for activation of pathogen defence in parsley. Plant Cell 12, 1425-1440. doi: 10.2307/3871140

Boller, T., and Felix, G. (2009). A renaissance of elicitors: perception of microbe-associated molecular. Annu. Rev. Plant Biol. 60, 379-406. doi: 10.1146/annurev.arplant.57.032905.105346

Boutegrabet, L., Feket, A., Hertkorn, N., Papastamoulis, Y., Waffo-Teguo, P., Merillon, J. M., et al. (2011). Determination of stilbene derivates in Burgundy red wines by ultra high pressure liquid chromatography. Anal. Bioanal. Chem. 40, 1513-1521. doi: 10.1007/s00216-011-4879-5

Caillot, S., Rat, S., Tavernier, M. L., Michaud, P., Kovensky, J., Wadouachi, A., et al. (2012). Native and sulfated oligoglucuronans as elicitors of defencerelated responses inducing protection against Botrytis cinerea of Vitis vinifera. Carbohydr. Polym. 87, 1728-1736. doi: 10.1016/j.carbpol.2011.09.084

Chang, X., and Nick, P. (2012). Defence signalling triggered by flg22 and harpin is integrated into a different stilbene output in Vitis cells. PLOS ONE 7:e40446. doi: 10.1371/journal.pone.0040446

Clemente, A. (2000). Enzymatic protein hydrolysates in human nutrition. Trends Food Sci. Technol. 11, 254-262. doi: 10.1016/S0924-2244(01)00007-3 
Colla, G., Rouphael, Y., Canaguier, R., Svecova, E., and Cardarelli, M. (2014). Biostimulant action of a plant-derived protein hydrolysate produced through enzymatic hydrolysis. Front. Plant Sci. 5:448. doi: 10.3389/fpls.2014. 00448

Coutos-Thévenot, P., Poinssot, B., Bonomelli, A., Yean, H., Breda, C., Buffard, D., et al. (2001). In vitro tolerance to Botrytis cinerea of grapevine $41 \mathrm{~B}$ rootstock in transgenic plants expressing the stilbene synthase Vst1 gene under the control of a pathogen inducible PR10 promoter. J. Exp. Bot. 358, 901-910. doi: 10.1093/jexbot/52.358.901

Delaunois, B., Farace, G., Jeandet, P., Clément, C., Baillieul, F., Dorey, S., et al. (2013). Elicitors as alternative strategy to pesticides in grapevine? current knowledge on their mode of action from controlled conditions to vineyard. Environ. Sci. Pollut. Res. 21, 4837-4846. doi: 10.1007/s11356-013-1841-4

Dodds, P., and Rathjen, J. (2010). Plant immunity: towards an integrated view of plant- pathogen interactions. Nat. Rev. Genet. 11, 539-548. doi: $10.1038 /$ nrg2812

Dubreuil-Maurizi, C., Trouvelot, S., Frettinger, P., Pugin, A., Wendehenne, D., and Poinssot, B. (2010). $\beta$-aminobutyric acid primes a NADPH oxidase-dependent reactive oxygen species production during grapevine triggered immunity. Mol. Plant Microbe Interact. 23, 1012-1021. doi: 10.1094/MPMI-23-8-1012

Dufour, M. C., Lambert, C., Bouscaut, J., Mérillon, J. M., and Corio-Costet, M. F. (2013). Benzothiadiazole-primed defence responses and enhanced differential expression of defence genes in Vitis vinifera infected with biotrophic pathogens Erysiphe necator and Plasmopara viticola. Plant Pathol. 62, 370-382. doi: 10.1111/j.1365-3059.2012.02628.x

Fadaei, V. (2012). Milk Proteins-derived antibacterial peptides as novel functional food ingredients. Ann. Biol. Res. 3, 2520-2526.

Fritig, B., Heitz, T., and Legrand, M. (1998). Antimicrobial proteins in induced plant defence. Curr. Opin. Immunol. 10, 16-22.

Galletti, R., Denoux, C., and Gambetta, S. (2008). The AtrbohD-mediated oxidative burst elicited by oligogalacturonides in Arabidopsis is dispensable for the activation of defense responses effective against Botrytis cinerea. Plant. Physiol. 148, 1695-1706. doi: 10.1104/pp.108.127845

Garcia-Brugger, A., Lamotte, O., Vandelle, E., Bourque, S., Lecourieux, D., Poinssot, B., et al. (2006). Early signaling events induced by elicitors of plant defenses. Mol. Plant Microbe Interact. 19, 711-724. doi: 10.1094/MPMI19-0711

Gauthier, A., Trouvelot, S., Kelloniemi, J., Frettinger, P., Wendehenne, D., Daire, X., et al. (2014). The sulfated laminarin triggers a stress transcriptome before priming the SA- and ROS-dependent defenses during grapevine's induced resistance against Plasmopara viticola. PLOS ONE 9:145. doi: 10.1371/journal.pone.0088145

Gfeller, A., Baerenfaller, K., Loscos, J., Chetelat, A., Baginsky, S., and Farmer, E. E. (2011). Jasmonate controls polypeptide patterning in undamaged tissue in wounded Arabidopsis leaves. Plant Physiol. 156, 1797-1807. doi: 10.1104/pp.111.181008

Giannakis, C., Bucheli, C. S., Skene, K. G. M., Robinson, S. P., and Steele Scott, N. (1998). Chitinase and $\beta$-1,3-glucanase in grapevine leaves: a possible defence against powdery mildew infection. Aust. J. Grape Wine 4, 14-22.

Gibbs, B. F., Zougman, A., Masse, R., and Mulligan, C. (2003). Production and characterization of bioactive peptides from soy hydrolysate and soy-fermented food. Food Res. Intern. 37, 123-131. doi: 10.1016/j.foodres.2003.09.010

Glazebrook, J. (2005). Contrasting mechanisms of defense against biotrophic and necrotrophic pathogens. Annu. Rev. Phytopathol. 43, 205-227. doi: 10.1146/annurev.phyto.43.040204.135923

Gobetti, M., Minervini, F., and Rizzello, C. G. (2004). Angiotensin i-converting enzyme-inhibitory and antimicrobial bioactive peptides. Intern. J. Dairy Technol. 57, 173-188. doi: 10.1111/j.1471-0307.2004.00139.x

Ippolito, A., and Sanzani, S. M. (2011). Control of postharvest decay by the integration of pre- and postharvest application of nonchemical compounds. Acta Hort. 905, 135-143.

Kido, E. A., Pandolfi, V., Houllou-Kido, L. M., Andrade, P. P., Marcelino, F. C., Nepomuceno, A. L., et al. (2010). Plant antimicrobial peptides: an overview of SuperSAGE transcriptional profile and a functional review. Curr. Protein Pept. Sci. 11, 220-230. doi: 10.2174/138920310791112110

Kimball, B. A., and Nolte, D. L. (2006). Development of a new deer repellent for the protection of forest resources. West. J. Appl. Forest. 21, 108-111.

Knight, H. (2000). Calcium signaling during abiotic stress in plants. Int. Rev. Cytol. 195, 269-234. doi: 10.1016/S0074-7696(08)62707-2
Kumar, S., Teotia, U. V. S., and Sanghi, A. (2013). Antioxidative property of cow milk caseinates hydrolyzed with different proteases. Int. J. Pharm. Sci. 5, 975-1491.

Lachhab, N., Sanzani, S. M., Boselli, M., and Ippolito, A. (2014). "Protein hydrolysates as resistance inducers against pre- and postharvest diseases," in Proceedings of the SOI Technical Meeting: Bio-stimulants, Corroborants, Resistance Inducers and Micronutrients in Fruit and Vegetable Crops (Ancona: Università Politecnica delle Marche), 14.

Lachhab, N., Sanzani, S. M., Fallanaj, F., Youssef, K., Nigro, F., Boselli, M., et al. (in press). Protein hydrolysates as resistance inducers for controlling green mould of citrus fruit. Acta Hort.

Laemmli, U. K. (1970). Cleavage of structural proteins during the assembly of the head of bacteriophage T4. Nature 227, 680-685.

Lecourieux, D., Mazars, C., Pauly, N., Ranjeva, R., and Pugin, A. (2002). Analysis and effects of cytosolic free calcium elevations in response to elicitors in Nicotiana plumbaginifolia cells. Plant Cell 14, 2627-2641. doi: 10.1105/tpc.005579

Lecourieux, D., Raneva, R., and Pugin, A. (2006). Calcium in plant defence-signalling pathways. New Phytol. 171, 249-269. doi: 10.1111/j.1469-8137.2006.01777.x

Link, V. L., Hofmann, M. G., Sinha, A. K., Ehness, R., Strand, M., and Roitsch, T. (2002). Biochemical evidence for the activation of distinct subsets of mitogenactivated protein kinases by voltage and defence-related stimuli. Plant Physiol. 128, 271-281. doi: 10.1104/pp.010569

Livak, K. J., and Schmittgen, T. D. (2001). Analysis of relative gene expression data using real-time quantitative PCR and the $2^{(-\Delta \Delta \mathrm{Ct})}$ method. Methods 25, 402-408. doi: 10.1006/meth.2001.1262

Lu, H., Slimian, S., Gamelin, E., Wang, G., and Fedrowski, J. (2009). Genetic analysis of acd6-1 reveals complex defense networks and leads to identification of novel defense genes in Arabidopsis. Plant J. 58, 401-412. doi: 10.1111/j.1365313X.2009.03791.x

Malacarne, G., Vrhovsek, U., Zulini, L., Cestaro, A., Stefanini, M., Mattivi, F., et al. (2011). Resistance to Plasmopara viticola in a grapevine segregating population is associated with stilbenoid accumulation and with specific host transcriptional responses. BMC Plant Biol. 11:114. doi: 10.1186/1471-2229-11-114

Nürnberger, T., and Brunner, F. (2002). Innate immunity in plants and animals: emerging parallels between the recognition of general elicitors and pathogen-associated molecular patterns. Curr. Opin. Plant Biol. 5, 1-7. doi: 10.1016/S1369-5266(02)00265-0

Pauw, B., Van Duijn, B., and Kijne, J. W. (2004). Activation of the oxidative burst by yeast elicitor in Catharanthus roseus cells occurs independently of the activation of genes involved in alkaloid biosynthesis. Plant Mol. Biol. 55, 797-805. doi: 10.1007/s11103-004-1968-2

Pezet, R., Gindro, K., Viret, O., and Richter, H. (2004). Effects of resveratrol, viniferins and pterostilbene on Plasmopara viticola zoospore mobility and disease development. Vitis 43, 145-148.

Pezet, R., Perret, C., Jean-Denis, J. B., Tabacchi, R., Gindro, K., and Viret, J. L. (2003). $\delta$-Viniferin, a resveratrol dehydrodimer: one of the major stilbenes synthesized by stressed grapevine leaves. J. Agric. Food. Chem. 5, 5488-5492. doi: 10.1021/jf030227o

Phelan, M., Aherne, A., FitzGerald, J., and O’Brien, N. M. (2009). Casein-derived bioactive peptides: biological effects, industrial uses, safety aspects and regulatory status. Int. Dairy J. 19, 643-654. doi: 10.1016/j.idairyj.2009.06.001

Poinssot, B., Vandelle, E., Bentéjac, M., Adrian, M., Levis, C., Brygoo, Y., et al. (2003). The endopolygalacturonase 1 from Botrytis cinerea activates grapevine defense reactions unrelated to its enzymatic activity. Mol. Plant Microbe Interact. 16, 553-564 doi: 10.1094/MPMI.2003.16.6.553

Polesani, M., Bortesi, L., Ferrarini, A., Zamboni, A., Fasoli, M., Zadra, C., et al. (2010). General and species-specific transcriptional responses to downy mildew infection in a susceptible (Vitis vinifera) and a resistant ( $V$. riparia) grapevine species. BMC Genom. 11:117. doi: 10.1186/1471-2164-11-117

Qiao, F., Chang, X., and Nick, P. (2010). The cytoskeleton enhances gene expression in the response to the Harpin elicitor in grapevine. J. Exp. Bot. 61, 4021-4031. doi: 10.1093/jxb/erq221

Rentel, M. C., and Knight, M. R. (2004). Oxidative Stress-Induced Calcium Signaling in Arabidopsis. Plant Physiol. 135, 1471-1479 doi: 10.1104/pp.104.042663

Robert-Seilaniantz, A., Grant, M., and Jones, J. D. (2011). Hormone crosstalk in plant disease and defense: more than just jasmonate-salicylate antagonism. 
Annu. Rev. Phytopathol. 49, 317-343. doi: 10.1146/annurev-phyto-073009114447

Romanazzi, G., Feliziani, E., Santini, M., and Landi, L. (2013). Effectiveness of postharvest treatment with chitosan and other resistance inducers in the control of storage decay of strawberry. Postharv. Biol. Technol. 75, 24-27. doi: 10.1016/j.postharvbio.2012.07.007

Romeis, T. (2001). Protein kinases in the plant defense response. Curr. Opin. Plant Biol. 4, 407-414. doi: 10.1016/S1369-5266(00)00193-X

Sanzani, S. M., Schena, L., De Cicco, V., and Ippolito, A. (2012). Early detection of Botrytis cinerea latent infections as a tool to improve postharvest quality of table grapes. Postharv. Biol. Technol. 68, 64-71. doi: 10.1016/j.postharvbio.2012.02.003

Trdá, L., Fernandez, O., Boutrot, F., Heloir, M. C., Kelloniemi, J., Daire, X., et al. (2014). The grapevine flagellin receptor VvFLS2 differentially recognizes flagellin-derived epitopes from the endophytic growth promoting bacterium Burkholderia phytofirmans and plant pathogenic bacteria. New Phytol. 201, 1371-1384. doi: 10.1111/nph.12592

Trouvelot, S., Varnier, A., Allegre, M., Mercier, L., Baillieul, F., Arnould, C., et al. (2008). A $\beta-1,3$ glucan sulfate induces resistance in grapevine against Plasmopara viticola through priming of defense responses, including HR-like cell death. Mol. Plant Microbe Interact. 21, 232-243. doi: 10.1094/MPMI-21-20232

Tuteja, N. (2009). "Integrated calcium signaling in plants," in Signaling and Communication in Plants, eds F. Baluška and S. Mancuso (Berlin; Heidelberg: Springer), 29-49. doi: 10.1007/978-3-540-89228-1_2

Vandelle, E., Poinssot, B., Wendehenne, D., Bentejac, M., and Pugin, A. (2006). Integrated signalling network involving calcium, nitric oxide, and active oxygen species but not mitogen-activated protein kinases in BcPG1-elicited grapevine defences. Mol. Plant Microbe. Interact. 19, 429-440. doi: 10.1094/MPMI19-0429

Van Loon, L. C., Rep, M., and Pieterse, C. M. (2006). Significance of inducible defense related proteins in infected plants. Annu. Rev. Phytopathol. 44, 135-162. doi: 10.1146/annurev.phyto.44.070505. 143425

Conflict of Interest Statement: The authors declare that the research was conducted in the absence of any commercial or financial relationships that could be construed as a potential conflict of interest.

Received: 04 October 2014; accepted: 28 November 2014; published online: 23 December 2014.

Citation: Lachhab N, Sanzani SM, Adrian M, Chiltz A, Balacey S, Boselli M, Ippolito $A$ and Poinssot B (2014) Soybean and casein hydrolysates induce grapevine immune responses and resistance against Plasmopara viticola. Front. Plant Sci. 5:716. doi: 10.3389/fpls.2014.00716

This article was submitted to Plant-Microbe Interaction, a section of the journal Frontiers in Plant Science.

Copyright (๑) 2014 Lachhab, Sanzani, Adrian, Chiltz, Balacey, Boselli, Ippolito and Poinssot. This is an open-access article distributed under the terms of the Creative Commons Attribution License (CC BY). The use, distribution or reproduction in other forums is permitted, provided the original author(s) or licensor are credited and that the original publication in this journal is cited, in accordance with accepted academic practice. No use, distribution or reproduction is permitted which does not comply with these terms. 